\title{
Does Medical Presence Decrease the Perceived Risk of Substance-Related Harm at Music Festivals? - CORRIGENDUM
}

Matthew Brendan Munn; ${ }^{1}$ Melissa Sydney White $;{ }^{2}$ Alison Hutton; ${ }^{3}$ Sheila Turris; ${ }^{1}$ Haddon Rabb $;{ }^{4}$ Adam Lund; Jamie Ranse ${ }^{4}$

1. UBC Emergency Medicine, Vancouver, https://doi.org/10.1017/S1049023X19002656; Published by Cambridge University Canada

2. UBC Southern Medical Program, Kelowna, Canada

3. University of Newcastle, Australia

4. UBC Mass Gathering Medicine Interest Group, Canada

In the original publication of the abstract, "Does Medical Presence Decrease the Perceived Risk of Substance-Related Harm at Music Festivals?" the name of author Haddon Rabb was misspelled. ${ }^{1}$ The abstract has been corrected.

Reference

1. Munn MB, White MS, Hutton A, et al. Does medical presence decrease the perceived risk of substance-related harm at music festivals? Prehosp Disaster Med. 2019;34(Suppl 1):s123. 